\title{
Effects of the s-Triazine Herbicide Turbutryn on Mitosis, Chromosomes and Nucleic Acids in Root Tips of Vicia faba
}

\author{
A. Badr 1
}

Botany Department, Faculty of Science, Tanta University, Tanta, Egypt

Accepted March 6, 1985

The mitodepressive and chromotoxic activities of herbicides in crop plants are well reported (Ennis 1948, Wuu and Grant 1966, Gichner et al. 1968, Tobgy et al. 1969, Tomkins and Grant 1972, Amer and Farah 1974, 1976, Badr 1979, Badr and Elkington 1982, Badr 1983). The induction of chromosomal anomalies by herbicides has been found to be associated with an action of these chemicals on DNA and RNA (Mohandas and Grant 1972, Cartwright 1976, Chand and Roy 1982, Badr et al. 1984). However, studies of the effect of these compounds on cell division and chromosomes in relation to their action on the nucleic acids have not been sufficiently carried out.

Few s-triazine herbicides have been investigated for their ability to affect mitosis and to produce chromosomal anomalies (Liang et al. 1967, Wuu and Grant 1966, Badr 1983). The effect of none of these compounds on DNA and RNA in dividing cells was not studied. In this paper the cytogenetic acitivities of the s-triazine herbicide turbutryn and its ability to affect DNA and RNA contents in the root tips of Vicia faba are reported.

Materials and methods

Turbutryn is the common name of 4-ethylamino-2tert butylamino-6-methylthios-triazine and controls several mono- and dicotylendonous weeds in a number of crop plants. In this study a formula containing $50 \%$ a.i. of turbutryn was used. The Egyptian variety Giza 1 of $V$. faba has been used as a test material in this investigation. Seeds were soaked in tap water for 24 hours and were then transferred to pots filled with moist sand for germination. Actively growing roots were treated with 4 different concentrations for 3,6,12 and 24 hours. The concentrations used were $4,20,100$ and $500 \mathrm{ppm}$ respectively. Control roots were simultaneously treated with tap water.

For cytological preparations root tips were fixed in $3: 1(\mathrm{v} / \mathrm{v})$ ethanol/glacial acetic acid for 24 hours and slides were prepared using the Feulgen squash technique. Six slides from each treatment were examined for the effects on the mitotic index (MI) and for chromosomal anomalies in dividing cells.

DNA and RNA were extracted by crushing $0.5 \mathrm{~g}$. root tips in $4 \mathrm{ml}$ Tris-EDTA buffer $(0.05 \mathrm{M}$ Tris. $+0.1 \mathrm{M} \mathrm{NaCl}+0.1$ EDTA, $\mathrm{pH}=8)$ mixed with $1 \mathrm{ml} 1 \%$ SDS

1 Present address: College of Education, King Abdulaziz University P. O. Box 344, Madinah Munawwarah, Saudi Arabia. 
(sodium dodecylsulphate) and $1 \mathrm{ml}$ SSC solution $(0.0015 \mathrm{M}$ trisodium citrate+ $0.015 \mathrm{M} \mathrm{NaCl}, \mathrm{pH}=7$ ). To remove proteins, fats and other fractions the extract was mixed with $4 \mathrm{ml}$ chloroform and isoamyl alcohol $(24: 1 \mathrm{v} / \mathrm{v})$ and centrifuged at $4000 \mathrm{rpm}$. The supernatant contained the nucleic acids.

The amount of DNA was determined by mixing $2 \mathrm{ml}$ of the supernatant with $1 \mathrm{ml} \mathrm{30 \%} \mathrm{perchloric} \mathrm{acid} \mathrm{and} 6 \mathrm{ml}$ of Burton reagent. The mixture was kept at $30^{\circ} \mathrm{C}$ for 17 hours. (Burton reagent $=3 \mathrm{~g}$. diphenyl amine in $200 \mathrm{ml}$ acetic acid $+\mathrm{ml}$ conc. sulphuric acid $+1 \mathrm{ml}$ of 1.6 acetaldehyde). Following this incubation the optical density of the solution was measured using a Spekol Karl-Zeiss spectrophotometer at $595 \mathrm{~nm}$ and the amount of DNA was calculated from a standard curve.

For the determination of RNA $1 \mathrm{ml}$ of the extract was mixed with $1 \mathrm{ml} 0.1 \mathrm{~g}$. $\mathrm{FeCl}_{3}$ dissolved in $100 \mathrm{ml} 37 \% \mathrm{HCl}$ and $5 \mathrm{~g}$. orcin. This mixture was then heated in a water bath for 15 minutes, cooled and the volume was adjusted to $4 \mathrm{ml}$ with the buffer used for extraction. The optical density was then measured at $670 \mathrm{~nm}$. The amount of RNA was calculated from a standard curve. The standard error of the mean M1 and the mean amount of DNA and RNA and of the average total chromosomal anomalies was calculated as a measure of variation, in these parameters, within every treatment.

\section{Results and discussion}

The effects of the different treatments of turbutryn on M1 and the amounts of DNA and RNA in root tips of $V . f a b a$ are given in Table 1 . The $3 \mathrm{~h}$ treatments have only resulted in slight increases in M1 values, particularly when the two lower concentrations ( 4 and $20 \mathrm{ppm}$ ) were applied. Of the $3 \mathrm{~h}$ treatments only the highest concetration ( $500 \mathrm{ppm}$ ) has slightly reduced the amounts of DNA and RNA. Prolonged treatments, however, resulted in the inhibition of mitotic activity (reduced M1 values) and reduction of the amounts of DNA and RNA in dividing cells of root meristems. The degree of mitotic inhibition is clearly dose dependent. M1 value was reduced as the concentration of the herbicide was increased and the period of treatment was prolonged. The reduction in the amount of DNA and RNA is closely associated with the inhibition of mitotic activity.

The inhibition of mitotic acitvity induced by turbutryn resembles the action of several other herbicides. These include some substituted urea compounds (Wuu and Grant 1966, Tomkins and Grant 1972, E1-Sadek and Ashour 1978, Badr and Elkington 1982), some substituted phenols (Mohandas and Grant 1972, Chand and Roy 1981), carbamates (Ennis 1948, Amer and Farah 1974), nitralin (Badr 1979), amitole (Bartels and Wolf 1965, Mohandas and Grant 1972), maleic hydrazide (Evans and Scott 1964) and some others. Tomkins and Grant (1972) and Badr and Elkington (1982) concluded that the substituted urea herbicides metobromuron and isopromuron may inhibit DNA synthesis which results in lower M1 values. Similarly Scott (1968) suggested that maleic hydrazide inhibits DNA replication. Chand and Roy (1981) proposed that 2,4-dinitrophenol inhibts DNA and RNA synthesis by reducing the oxidative phosphorylation in plants resulting in lower levels of ATP. This supports the hypothesis of Ashton and Crafts (1973) that 
herbicides that reduce ATP are strong inhibitors of RNA and protein synthesis.

Turbutryn induced a wide range of chromosomal anomalies in the root tips of $V$. faba. The percentage cells showing abnormalities is also given in Table 1. The $3 \mathrm{~h}$ and $6 \mathrm{~h}$ treatments were indifferent with regard to the percentage of total chromosomal abnormalities produced, but $12 \mathrm{~h}$ and $24 \mathrm{~h}$ treatments resulted in higher percentage of abnormal dividing cells. In general the percentage of dividing cells showing chromosomal anomalies increased with the increase of herbicide concentration. Considerable increase of abnormalities was recorded as the period of treatment was prolonged from $6 \mathrm{~h}$ to $12 \mathrm{~h}$ and from $12 \mathrm{~h}$ to $24 \mathrm{~h}$ (Table 1).

Table 1. Effects of the different treatments of turbutryn on M1, the amounts of DNA and the percentage of chromosomal abnormalities in root tips of $V . f a b a$

\begin{tabular}{|c|c|c|c|c|c|c|c|c|}
\hline \multirow{3}{*}{$\begin{array}{c}\text { Treatment } \\
\text { conc. ppm } \\
3 \text { h Cont. } \\
4\end{array}$} & \multicolumn{2}{|c|}{$\mathbf{M} 1 \pm \mathrm{SE}^{+}$} & \multicolumn{2}{|c|}{$\underset{\mu \mathrm{g}}{\mathrm{DNA}} \pm \underset{\mathrm{g}}{\mathrm{SE}}$} & \multicolumn{2}{|c|}{$\underset{\mu \mathrm{g}}{\mathrm{RNA}} \pm \underset{\mathbf{g}}{\mathrm{SE}}$} & \multicolumn{2}{|c|}{$\underset{\text { percentage }}{\text { Chrom. abn. }} \pm \mathrm{SE}$} \\
\hline & 10.9 & 0.32 & 165 & 4.5 & 286 & 5.2 & 2.4 & 0.44 \\
\hline & 12.1 & 0.29 & 168 & 5.3 & 286 & 6.4 & 28.6 & 0.94 \\
\hline 20 & 11.8 & 0.35 & 167 & 4.3 & 277 & 5.1 & 34.2 & 1.16 \\
\hline 100 & 10.9 & 0.22 & 164 & 5.7 & 285 & 4.7 & 41.1 & 2.35 \\
\hline 500 & 10.6 & 0.32 & 158 & 6.1 & 278 & 5.4 & 40.8 & 1.48 \\
\hline $6 \mathrm{~h}$ Cont. & 10.5 & 0.22 & 172 & 3.5 & 280 & 4.3 & 2.0 & 0.44 \\
\hline 4 & 10.0 & 0.32 & 168 & 2.8 & 270 & 3.5 & 26.1 & 1.64 \\
\hline 20 & 10.2 & 0.62 & 162 & 4.3 & 265 & 2.8 & 34.5 & 1.16 \\
\hline 100 & 9.4 & 0.22 & 151 & 4.7 & 255 & 4.7 & 38.6 & 2.14 \\
\hline 500 & 8.4 & 0.32 & 141 & 3.2 & 242 & 4.7 & 40.3 & 1.48 \\
\hline $12 \mathrm{~h}$ Cont. & 9.7 & 0.35 & 169 & 5.2 & 295 & 5.4 & 1.8 & 0.32 \\
\hline 20 & 7.7 & 0.22 & 151 & 4.3 & 271 & 4.2 & 40.1 & 1.16 \\
\hline 100 & 6.1 & 0.32 & 146 & 3.8 & 268 & 4.2 & 42.4 & 2.56 \\
\hline 500 & 5.8 & 0.35 & 122 & 2.6 & 248 & 4.1 & 50.2 & 1.48 \\
\hline 24 h Cont. & 10.2 & 0.22 & 176 & 4.4 & 292 & 4.4 & 2.6 & 0.32 \\
\hline 4 & 8.2 & 0.22 & 144 & 4.5 & 262 & 3.8 & 41.0 & 2.32 \\
\hline 20 & 6.8 & 0.32 & 138 & 3.6 & 254 & 3.8 & 45.4 & 2.16 \\
\hline 100 & 5.9 & 0.35 & 115 & 2.7 & 230 & 2.9 & 49.5 & 1.48 \\
\hline 500 & 5.1 & 0.35 & 107 & 2.1 & 216 & 3.4 & 53.4 & 2.34 \\
\hline
\end{tabular}

$+\mathrm{SE}=$ Standard error.

The types and frequency of chromosomal anomalies produced by the different treatments of turbutryn are shown in Table 2 and photographs of these abnormalities are illustrated in Figs. 1-10. The colchicine type metaphase configurations (Fig. 1) were the major abnormality produced by all treatments. Multipolar anaphase and telophase figures (Fig. 2) were also observed in considerable frequency by all treatments. C-anaphase configurations (Fig. 3 ) in which the two chromatids of C-metphase chromosomes are separated and chromosome lagging (Fig. 4) were recorded in lower frequencies by all treatments, whereas, polyloidy (Fig. 5) was only observed following the $24 \mathrm{~h}$ treatments. Chromosomal bridges (Fig. 6) and chromosome breakage (Fig. 7) were induced by all treatments; their frequency increased with increased concentration and prolonged period of treatment. Chromosomal stickiness (Fig. 8) was not observed after the $3 \mathrm{~h}$ treatments, but was recorded in considerably 

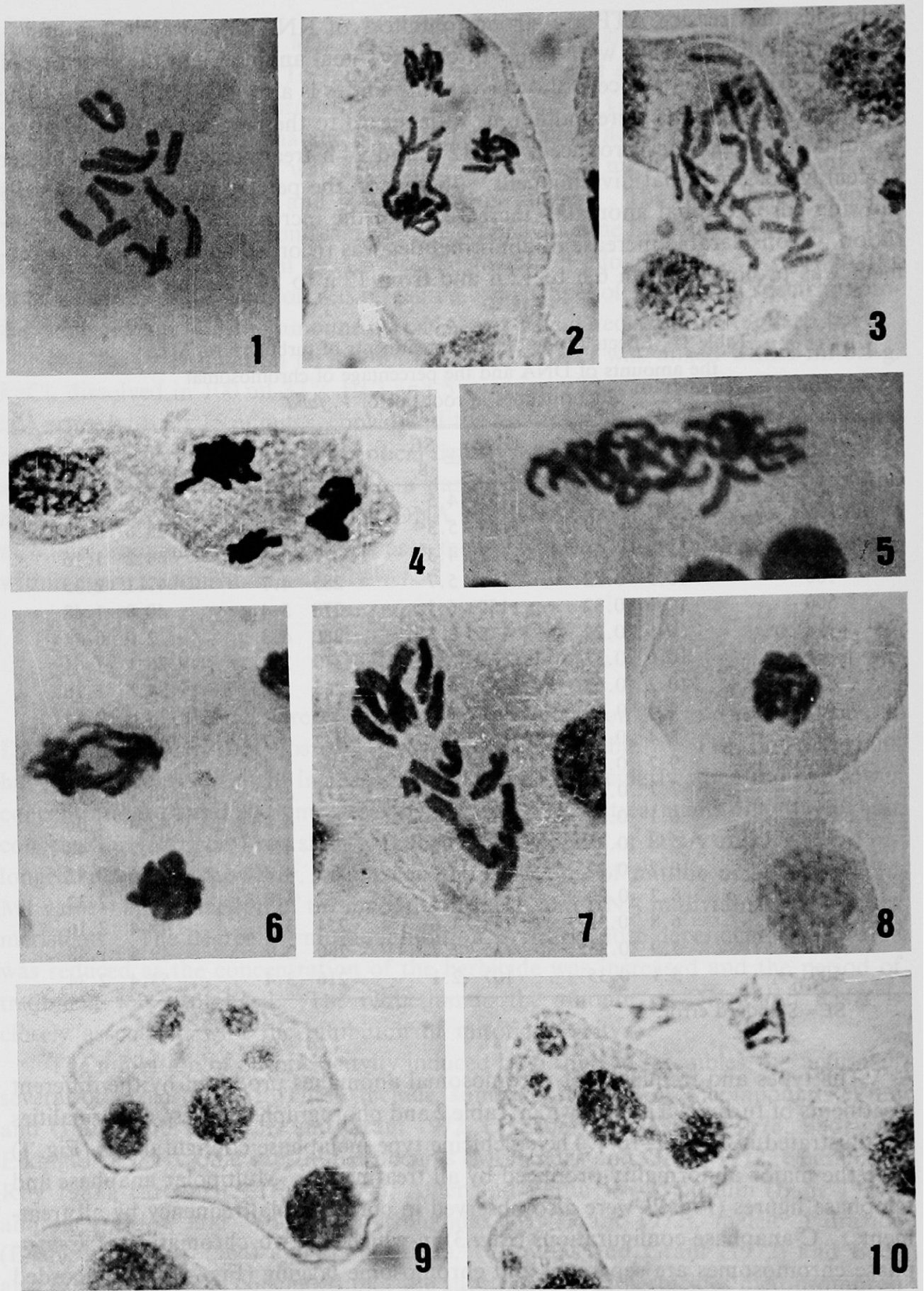

Figs. 1-10. Types of chromosomal abnormalities induced by the herbicide turbutryn in the root tips of $V . f a b a . \quad 1, C$-metaphase $3 \mathrm{~h} ; 4 \mathrm{ppm} . \quad 2$, multipolar anaphase $6 \mathrm{~h} ; 4 \mathrm{ppm} . \quad 3$, C-anaphase $6 \mathrm{~h} ; 4 \mathrm{ppm}$. 4, chromosome lagging $6 \mathrm{~h} ; 20 \mathrm{ppm}$. 5, S: polyploidy $24 \mathrm{~h} ; 100 \mathrm{ppm}$. 6, chromosomal bridges and stickiness $24 \mathrm{~h}, 500 \mathrm{ppm}$. 7, chromosome breakage $12 \mathrm{~h}, 100 \mathrm{ppm}$. 8, stickiness $24 \mathrm{~h} ; 100 \mathrm{ppm}$. 9, 9, micronuclei $24 \mathrm{~h} ; 20 \mathrm{ppm}$. 10, chromatin bridge $24 \mathrm{~h} ; 100 \mathrm{ppm}$. 
high proportions following both the $12 \mathrm{~h}$ and $24 \mathrm{~h}$ treatments. Abnormal figures not included in one of these types have been referred to as disturbed figures; their frequency is given in Table 2. Some abnormal interphase cells were observed following the $6 \mathrm{~h}, 12 \mathrm{~h}$ and $24 \mathrm{~h}$ treatments. These were comprised of multinucleated cells and cells containing micronuclei (Fig. 9) and chromatin bridges (Fig. 10). The percentage of abnormal interphase cells is also given in Table 2.

Table 2. Types and percentage of chromosomal abnormalities produced by the different treatments of turbutryn in root tips of $V$. faba

\begin{tabular}{ccccccccccc}
\hline $\begin{array}{c}\text { Treat- } \\
\text { ment } \\
\text { conc. }\end{array}$ & C-M & C-A & $\begin{array}{c}\text { Multi. } \\
\text { A+T }\end{array}$ & Lagg. & $\begin{array}{c}\text { Poly- } \\
\text { ploidy }\end{array}$ & Bridge & Break & Stick & Dist. & $\begin{array}{c}\text { Abn. } \\
\text { int. }\end{array}$ \\
\hline 3h Cont. & & & & & & & & & 100 & \\
4 & 82.1 & 3.5 & 10.4 & 2.9 & 0.0 & 0.0 & 0.0 & 0.0 & 2.1 & 0.0 \\
20 & 78.6 & 2.4 & 12.3 & 2.6 & 0.0 & 2.1 & 0.0 & 0.0 & 1.7 & 0.0 \\
100 & 79.2 & 1.4 & 11.5 & 2.7 & 0.0 & 2.4 & 0.0 & 0.0 & 2.8 & 0.0 \\
500 & 81.7 & 2.7 & 10.3 & 2.0 & 0.0 & 1.8 & 0.0 & 0.0 & 1.5 & 0.0 \\
6 h Cont. & & & & & & & & & 100 & \\
4 & 73.4 & 1.7 & 12.1 & 5.0 & 0.0 & 3.8 & 1.0 & 0.0 & 2.0 & 0.3 \\
20 & 72.6 & 2.2 & 11.6 & 4.2 & 0.0 & 5.6 & 1.0 & 1.0 & 2.0 & 0.2 \\
100 & 64.3 & 3.2 & 15.4 & 4.3 & 0.0 & 6.8 & 1.5 & 2.6 & 2.2 & 0.2 \\
500 & 58.8 & 2.8 & 17.4 & 4.9 & 0.0 & 8.3 & 1.2 & 5.2 & 1.8 & 0.2 \\
$12 \mathrm{~h} \mathrm{Cont.}$ & & & & & & & & & 100 & \\
4 & 64.5 & 2.2 & 15.5 & 3.4 & 0.0 & 3.2 & 2.1 & 8.0 & 1.9 & 0.4 \\
20 & 57.2 & 3.2 & 17.2 & 3.5 & 0.0 & 5.8 & 1.7 & 10.2 & 3.0 & 0.5 \\
100 & 52.8 & 2.7 & 16.4 & 2.6 & 0.0 & 6.8 & 3.0 & 16.6 & 2.7 & 0.5 \\
500 & 52.3 & 3.4 & 22.6 & 4.1 & 0.0 & 12.4 & 3.4 & 10.5 & 2.1 & 0.6 \\
$24 \mathrm{~h} \mathrm{Cont.}$ & & & & & & & & & 100 & \\
4 & 60.5 & 1.7 & 15.1 & 2.1 & 2.1 & 6.1 & 2.7 & 12.0 & 2.0 & 2.4 \\
20 & 55.2 & 2.3 & 16.1 & 1.8 & 2.4 & 8.6 & 3.1 & 16.4 & 2.8 & 3.6 \\
100 & 52.8 & 2.8 & 18.2 & 2.9 & 2.0 & 9.8 & 3.6 & 25.8 & 2.8 & 4.7 \\
500 & 48.6 & 2.8 & 19.6 & 3.1 & 3.0 & 14.7 & 3.5 & 29.7 & 3.8 & 5.4 \\
\hline
\end{tabular}

The types of chromosomal anomalies produced by turbutryn may be grouped in three classes. The first is often referred to as mitotic abnormalities and is the result of an action on the mitotic apparatus (Brogger 1977, Grant 1978). These include $\mathrm{C}$-metaphase, $\mathrm{C}$-anaphase, multipolar mitosis, polypoidy and chromosome lagging. These types of abnormalities have been induced by several herbicides (Ennis 1948, Crocker 1953, Liang et al. 1967, Amer and Farah 1974, Badr 1979, Badr and Elkington 1982, Badr 1983). Another class of anomalies observed is chromosomal stickiness which is also induced by several agricultural chemicals (Grant 1978). Stickiness is generally regarded as a physiological effect on chromosomes during division (Savage 1975) and has been considered as a category of chromatid aberration (Klasterska et al. 1976). The third class of chromosomal anomalies produced by turbutryn is chromosome aberrations including chromosome breakage. In this respect turbutryn resembles some other herbicides including substituted ureas, substituted phenols and s-triazine compounds (Wuu and Grant 1966, Ahmed and Grant 1972, Mohandas and Grant 1972, Badr and Elkington 1982, Badr et al. 1984). 
Chemicals which induce chromosome breakage are known to exert a clastogen action on chromosomes which is generally regarded to involve an action on DNA (Grant 1978).

A number of herbicides, which produced chromosomal anomalies similar to those produced by turbutryn, have been reported to induce mutation in higher plants. These include the s-triazine compounds atrazine and simazine (Wuu and Grant 1966), the substituted urea herbicides N-ethyl N-nitroso urea and N-methyl $\mathrm{N}$-nitroso urea (Gichner et al. 1968), EMS (Tomkins and Grant 1972) and maleic hydrazide (Gichner et al. 1982). The present results, therefore, add a new compound to the list of agricultural chemicals which, when used widely, may result in harmful damage to crop plants. The application of these chemicals must be strictly controlled and their capacity to induce cytogenetic activities in crop plants should be extensively studied.

\section{Summary}

Actively dividing root tips of Vicia faba were treated with 4 different concentrations of turbutryn for 3, 6, 12 and 24 hours. The concentrations used were 4, 20, 100 and $500 \mathrm{ppm}$ of the herbicide. Almost all treatments exerted a mitodepressive action and resulted in reductions in the amounts of DNA and RNA. Turbutryn produced a number of chromosomal anomalies. The types of abnormalities induced are comprised of mitotic abnormalities, which indicate an effect on the spindle apparatus, chromosomal stickiness and chromosomal aberrations including chromosome breakage. The mitodepressive action of turbutryn is remarkably associated with the ability of this herbicide to reduce the amounts of DNA and RNA and its capacity to induce chromosomal anomalies.

\section{References}

Ahmed, S. and Grant, W. F. 1972. Cytological effects of the pesticides Phosdrin and Bladex on Tradescantia and Vicia faba. Can. J. Genet. Cytol. 14: 157-165.

Amer, S. M. and Farah, O. R. 1974. Cytological effects of pesticides VII. Mitotic effects of isopropyl-N-phenyl carbamate and duphar. Cytologia 40: 21-29.

- and - 1976. Cytological effects of pesticides VIII. Effects of carbamate pesticides IPC, regor and duphar on Vicia faba. Cytologia 41: 597-606.

Ashton, F. M. and Crafts, A. S. 1973. Mode of Action of Herbicides. Wiley-Interscience Publ., New York.

Badr, A. 1979. Cytotoxic effects of the herbicide nitralin on mitosis in Allium cepa root tips. Delta J. Sci. 2: 24-38.

- 1983. Cytogenetic activities of a triazine herbicide in root tips of Allium cepa and Vicia faba. Mutat. Res. 117: 173-182.

- and Elkington, T. T. 1982. Antimitotic and chromotoxic activities of isoproturon in Allium cepa and Hordeum vulgare. Environmental and Experimental Botany 22: 265-270.

-, Mohamed, Y. A. H. and Selim, E. E. 1983. Effects of herbicide diuron on mitosis, chromosomes and nucleic acids in root tips of Vicia faba and Hordeum vulgare. Delta J. Sci. 7: $650-676$.

Bartels, P. G. and Wolf, F. T. 1965. The effect of amitrole upon nucleic acids and protein metabolism of wheat seedlings. Physiol. Plant. 18: 805-812. 
Brogger, A. 1977. Chromosome damage in human mitotic cells after in vivo and in vitro exposure to mutagens. In Export Conference on Genetic Damage in Man Caused by Environmental Agents. Oslo Academic Press, New York, 1978.

Cartwright, P. M. 1976. Effects of herbicides on cell division. In Herbicides, Physiology, Biochemistry and Ecology (Andus, L. J. ed.). Academic Press, New York.

Chand, S. and Roy, S. C. 1981. Effects of herbicide 2,4-dinitrophenol on mitosis, DNA, RNA, and protein synthesis in Nigella sativa L. Biologia Plantarum (Praha) 23: 198-202.

Crocker, B. H. 1953. Effect of 2,4-dichlorophenoxyacetic acid and 2,4,5-trichlorophenoxyacetic acid on mitosis in Allium cepa. Bot. Gaz. 114: 274-283.

El-Sadek, L. M. and Ashour, F. M. 1978. A comparative study of the effect of fluometuron on wheat and broad beans root meristems. Egypt. J. Bot. 21 : 161-170.

Ennis, W. B. 1948. Responses of crop plants to isopropyl-N-phenyl carbamate. Bot. Gaz. 109: 473-493.

Evans, H. J. and Scott, D. 1964. Influence of DNA synthesis on the production of chromatid aberration by X-rays and maleic hydrazide in Vicia faba. Genetics 49: 17-38.

Gichner, T., Gaul, H. and Omura, T. 1968. The influence of post treatment washing and redrying of barley seeds on the mutagenic activity of $\mathrm{N}$-methyl-N-nitroso urea and $\mathrm{N}$-ethyl-Nnitroso urea. Radiation Botany 8: 499-507.

-, Veleminsky, J. and Pokorny, V. 1982. Somatic mutation induced by maleic hydrazide and its potassium and diethanolamine salts in the Tradescantia. Mutat. Res. 103: 289-293.

Grant, W. F. 1978. Chromosome aberrations in plants as monitering system. Environ. Health Perspectives 27: 289-293.

Klasterska, I., Natarajan, A. T. and Romel, C. 1976. An interpretation of the origin of subchromatid aberrations and chromosome stickiness as a category of chromatid aberration. Hereditas 83: 153.

Liang, G. H. L., Feltener, K. C., Liang, Y. T. S. and Morril, J. Z. 1967. Cytogenetic effects and responses of agronomic characters in grain sorghum, Sorghum vulgare Pen. following atrazine application. Crop Sci. 7: 245-248.

Mohandas, T. and Grant, W. F. 1972. Cytogenetic effects of 2, 4-D and amitrole and relation to nuclear volume and DNA content in some higher plants. Can. J. Genet. Cytol. 14: 773-783.

Savage, J. R. K. 1975. Classification and relationships of induced chromosomal structural changes. J. Med. Gen. 12: 103-122.

Scott, D. 1968. The additive effect of X-rays and maleic hydrazide in inducing chromosomal aberrations at different stages of the mitotic cycle in Vicia faba. Mutat. Res. 5: 65-92.

Tobgy, A. H., Selim, A. R. and Farag, S. 1969. Effects of the herbicide CIPC (isopropyl-N-3chlorophenyl carbamate) on mitosis in root tips of Allium cepa. L. and Vicia faba L. Bull. Fac. Agric. Cairo Univ. 20: 245-257.

Tomkins, D. J. and Grant, W. F. 1972. Comparative cytological effects of the pesticides Menazon, Metobromuron and tetrachloroi-isophthalonitrile in Hordeum and Tradescantia. Can. J. Genet. Cytol. 14: 245-256.

Wuu, K. D. and Grant, W. F. 1966. Morphological and somatic chromosomal aberrations induced by pesticides in barley (Hordeum vulgare). Can. J. Genet. Cytol. 8: 481-501. 